\begin{abstract}
Iranica
Abstracta Iranica Revue bibliographique pour le domaine irano-aryen

Volume 40-41 | 2019

Comptes rendus des publications de 2017-2018
\end{abstract}

\title{
Mark Woolmer. A Short History of the Phoenicians
}

\section{Reinhard Pirngruber}

\section{OpenEdition}

\section{Journals}

Electronic version

URL: http://journals.openedition.org/abstractairanica/50086

DOI: 10.4000/abstractairanica.50086

ISBN: 1961-960X

ISSN: 1961-960X

Publisher:

CNRS (UMR 7528 Mondes iraniens et indiens), Éditions de l'IFRI

Electronic reference

Reinhard Pirngruber, "Mark Woolmer. A Short History of the Phoenicians", Abstracta Iranica [Online], Volume 40-41 | 2019, document 88, Online since 30 December 2019, connection on 18 April 2021 URL: http://journals.openedition.org/abstractairanica/50086 ; DOI: https://doi.org/10.4000/ abstractairanica. 50086

This text was automatically generated on 18 April 2021.

Tous droits réservés 


\title{
Mark Woolmer. A Short History of the Phoenicians
}

\author{
Reinhard Pirngruber
}

\section{REFERENCES}

Mark Woolmer. A Short History of the Phoenicians. London/New York: Bloomsbury Academic/I.B. Tauris, 2017, 256p., ill.

1 This volume provides a succinct introduction to history and culture of the Phoenicians from the Bronze Age until the arrival of Alexander the Great. After an introduction attempting to give a definition of "Phoenician" and outlining the geographic and climatic background as well as the available written sources, the first chapter is dedicated the political history of the region; pp.47-53 deal with the Achaemenid period.

2 The ensuing chapters are not diachronic in nature but rather synoptic overviews of select aspects of Phoenician history. The book focuses first on the social and economic (Chapter 2) and the religious (Chapter 3) history of Phoenicia, while chapter 4 is deals with the country's material culture. The final chapter 5 is analysis of Phoenician expansionism.

\section{AUTHORS}

\section{REINHARD PIRNGRUBER}

Institut für Orientalistik, Wien 